\title{
Biocontainer Use in a Petunia $\times$ hybrida Greenhouse Production System: a Cradle-to-gate Carbon Footprint Assessment of Secondary Impacts
}

\author{
Andrew K. Koeser ${ }^{1}$ \\ Department of Environmental Horticulture, Center For Landscape \\ Conservation and Ecology, IFAS, University of Florida-Gulf Coast Research \\ and Education Center, 14625 County Road 672, Wimauma, FL 33598
}

Sarah T. Lovell

Department of Crop Sciences, University of Illinois at Urbana-Champaign, 1009 Plant Sciences Laboratory, 1201 S. Dorner Drive, Urbana, IL 61801

\author{
Aaron C. Petri \\ Smart Energy Design Assistance Center (SEDAC), University of Illinois at \\ Urbana-Champaign, 1 Saint Mary's Road, Champaign, IL 61820
}

Robin G. Brumfield

Department of Agricultural, Food, and Resource Economics, Rutgers University, 55 Dudley Road, New Brunswick, NJ 08901

\section{J. Ryan Stewart \\ Department of Plant and Wildlife Sciences, Brigham Young University, 167 WIDB, Provo, UT 84602}

Additional index words. global warming potential, life cycle assessment, pots, sustainability

\begin{abstract}
This study assessed the material and energy inputs required to produce a Petunia $\times$ hybrida plant from initial propagation to delivery at a regional distribution center. Impacts were expressed in terms of their contribution to the carbon footprint or global warming potential (GWP) of a single finished plant in a $\approx 10-\mathrm{cm}$ diameter container. Beyond this baseline assessment, the study investigated the secondary impacts (e.g., irrigation demand) associated with container type used. Life cycle assessment data were sourced from interviews, published literature, propriety data sources, direct metering at the greenhouse facility, and original findings from a series of university greenhouse experiments. Results show that a traditional plastic container accounts for $\approx 16 \%$ of overall $\mathrm{CO}_{2} \mathrm{e}$ emissions $(0.544 \mathrm{~kg})$ during petunia production. Although the container was a significant contributor to GWP, electrical consumption for supplemental lighting and irrigation during plug production proved to be the leading source of $\mathrm{CO}_{2}$ e emissions (over 47\%) in our model system. Differences in GWP when considering secondary impacts associated with the various biocontainers were minor, especially when compared with the other elements of production. Our results demonstrate that biocontainers could potentially be as or more sustainable than plastic pots once pot manufacturing and end-of-life data are considered. However, use of more efficient supplemental lighting sources may ultimately have the greatest impact on overall GWP for the production system assessed.
\end{abstract}

Environmentally conscious consumers are generally willing to pay higher prices for sustainably produced goods and demonstrate loyalty to the retailers supplying them (Dennis

\footnotetext{
Received for publication 28 Oct. 2013. Accepted for publication 31 Dec. 2013.

This research was partially funded by the USDA Specialty Crops Research Initiative Grant program with matching resources from the University of Illinois College of Agricultural, Consumer and Environmental Sciences.

${ }^{1}$ To whom reprint requests should be addressed; e-mail: akoeser@ufl.edu.
}

et al., 2010; Krug et al., 2008; Yue et al., 2011). However, not all efforts to reduce the environmental impacts associated with commercial horticulture production have resulted in positive perceptions by the plant-buying public. For example, a recent study demonstrated that the adoption of organic fertilizers offered no significant marketing advantage for floriculture crops (Yue et al., 2011). In this same study, plants labeled as "organic" were actually viewed unfavorably by trial participants, although no explanation was given for this finding.

In contrast to organic labeling, the adoption of biocontainers (plant material-based, biodegradable pots) as an alternative to the use of conventional plastic containers can be a significant driver of consumer interest. Yue et al. (2011) found that biodegradable, compostable, and recycled pots had the greatest impact on consumer preference, outranking other sustainable production practices not seen directly at the garden retail center (e.g., efficient use of wholesale production space). Similar conclusions were drawn by Hall et al. (2010), who found container type contributed most to consumers' interest in sustainably produced plants, outranking other highly influential considerations such as price and carbon footprint.

Despite their perceived environmental benefits and appeal as alternatives to petroleumbased plastic pots, biocontainers have not been assessed to determine their overall impact on commercial greenhouse sustainability. In this regard, biocontainers have one obvious advantage over conventional plastic pots; they are not discarded and transported to a landfill after use. Rather, most biocontainers are designed to be planted directly into the landscape or composted in a home compost bin. Some bioplastics, however, may require commercial composting conditions to fully break down (David Evans, personal communication).

Although recycling plastic pots is an option for some consumers with access to collection facilities, containers used for greenhouse and nursery production are less likely to be reclaimed given the potential for chemical contamination and photodegradation (Garthe and Kowal, 1994). In the United States, overall, plastic recycling rates are estimated to be only 8\% [U.S. Environmental Protection Agency (EPA), 2011]. Within this aggregation, not all plastics and plastic products are recycled equally. More ubiquitous and desirable products such as bottles and jars have recycling rates ranging from $21 \%$ to $28 \%$ (US EPA, 2011). Lesser-valued agricultural plastics are generally buried or burned and are likely reclaimed at rates much lower than the overall average (Garthe and Kowal, 1994).

Beyond end-of-life considerations, container selection can have a number of impacts on the overall sustainability of greenhouse production. Biocontainers vary in their material and overall strength (Evans et al., 2010; Evans and Karcher, 2004), and they can be less resilient to the rigors of mechanization and transport (Koeser et al., 2013a). As such, overall production efficiency may decline as a result of losses linked to unacceptable container damage. For potted plants that successfully navigate through mechanized transplanting and handling processes, plant growth rate and water use in greenhousegrowing spaces can vary given differences in container design and porosity (Koeser et al., 2013b). Moving beyond issues associated with production, purchased plants introduced into the landscape may have different establishment and growth rates depending on the combination of species and plantable pot used (Kuehny et al., 2011).

This study offers a first look at the overall sustainability of biocontainers as part of 
a greenhouse production system. Hall et al. (2009) noted in their survey work that greenhouse growers believed sustainability in their operations was important. Additionally, the researchers found that decisions regarding sustainable practices were largely based on this belief and not an expectation of economic reward from environmentally conscious consumers. As such, our work adopts a grower's perspective and focuses on the environmental impacts of container use during the plant production phase (cradle-to-gate).

One of the main difficulties in any life cycle assessment (LCA) is the collection of quality data from manufacturers and contractors (Boustead, 1996). Although this is true even for in-house assessments, the transparency and potential scrutiny that come with publishing results in a peer-reviewed journal can be an added barrier to full cooperation. In this assessment, only the secondary impacts occurring during the greenhouse production of plants (e.g., differences in irrigation demand, peat use, etc.) associated with each container are compared. These secondary impacts were directly measured through a series of applied research trials and represent differences in inputs growers would note in their operations. The results of this work can be used to guide future research by identifying promising containers for future assessment (i.e., determining the carbon footprints for their manufacturing). Furthermore, providing container manufacturers with preliminary results from a relevant example of the LCA process may reduce their apprehension and encourage future participation.

Biocontainers as a whole are marketed as a means of making the horticultural industry more sustainable. This article aims to provide one piece of the puzzle in evaluating these claims by identifying the extent to which each container impacts the carbon footprint of petunia production. The results of this work will help commercial growers identify secondary environmental impacts associated with their decision to adopt green packaging in their production systems.

\section{Methods}

Goal, scope, and functional unit. This article assesses the inputs and impacts of a short-rotation greenhouse crop, Petunia $\times$ hybrida (petunia), from initial propagation to plant and container delivery at a retail center. This study is the first to establish a baseline, cradle-to-gate life cycle inventory of this annual floral commodity. Additionally, our article serves as an initial screening of nine commercially available biocontainers (Table 1; Fig. 1), which may be selected for a more thorough life cycle assessment that includes manufacturing inputs and environmental impacts in future research.

As a model system, our assessment is based on production practices of a large, semimechanized wholesale greenhouse that supplies retailers throughout the midwestern United States (Mid-American Growers, Granville, IL). This extensive 29-ha operation provides plant material for (among other clients) the nation's largest brick and mortar retail center in a $320-\mathrm{km}$ to $480-\mathrm{km}$ distribution range, which includes the Chicago, St. Louis, Indianapolis, and Milwaukee metropolitan areas (Flack, personal communication). GWP linked to carbon emissions was selected as the primary environmental impact estimated to allow for comparison with past life cycle assessment works in horticultural production (Aldentun, 2002; Ingram, 2012, 2013; Kendall and McPherson, 2012). The functional unit is a single petunia plant and its container $\left(\approx 450-\mathrm{cm}^{3}\right.$ volume, although volume was somewhat variable because of size availability for the containers assessed).

System boundaries and assumptions. The boundary for this cradle-to-gate LCA began with propagation through seed at the commercial greenhouse (Fig. 2). Actual seed production and transport were not included within the system boundary given limitations of available data and because past work has shown this process contributes very little to the overall impacts of production (rounded to 0\%; Kendall and McPherson, 2012). After germination, seedlings in our model system are grown in indoor greenhouse space until they are large enough to be transplanted from their initial plug tray cell to a larger, final container for outdoor production. Once plants are market-ready (i.e., a point at which a plant is in flower and above-ground growth is sufficiently filling the container), they are transported to a garden retail center for sale.

The scope of this assessment does not consider emissions associated with the production of capital goods (e.g., the greenhouses facilities and mechanized equipment) used to produce the functional unit. This conforms to international guidelines outlined in PAS20502011 and follows methods adopted by past LCA work in ornamental horticulture (British Standards Institute, 2011; Ingram, 2012; Kendall and McPherson, 2012).

Life cycle inventory and data collection. Data for this LCA came from a variety of

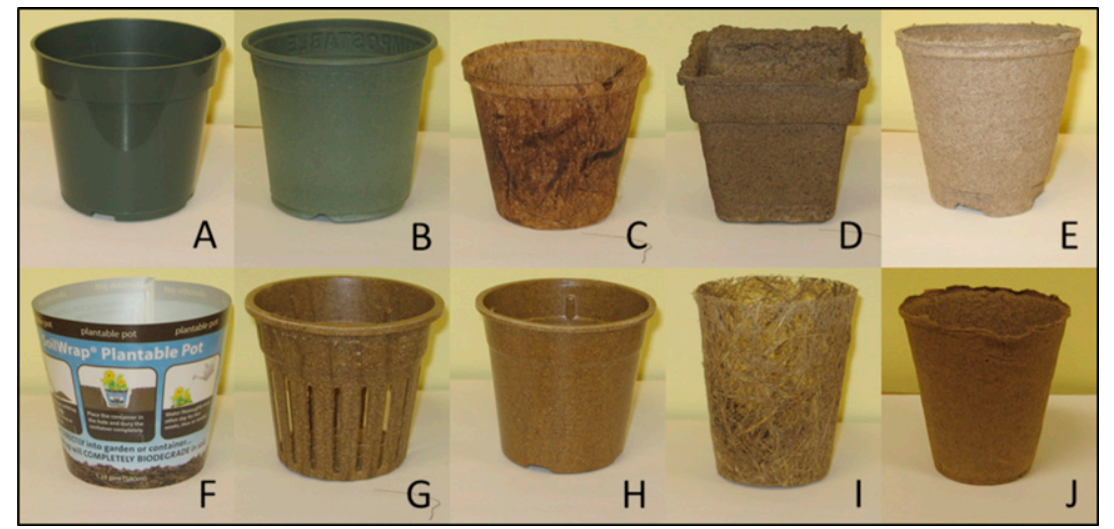

Fig. 1. Containers assessed in the life cycle assessment included (A) plastic control, (B) bioplastic, (C) coir, (D) manure, (E) peat, (F) sleeve, (G) slotted rice hull, (H) solid rice hull, (I) straw, and (J) wood fiber.

Table 1. Container type, product name, approximate volume, and manufacturer information for nine biocontainers and a conventional plastic container use for this life cycle assessment.

\begin{tabular}{|c|c|c|c|}
\hline Container type & Product name ${ }^{z}$ & Volume $\left(\mathrm{cm}^{3}\right)$ & Manufacturer \\
\hline Plastic & Dillen 04.00 Standard Thinwall Green & 480 & Myers Industries Lawn \& Garden Group, Middlefield, $\mathrm{OH}$ \\
\hline Bioplastic & TerraShell $^{\mathrm{TM}} 10-\mathrm{cm} \mathrm{H}$ Wheat Pot & 473 & Summit Plastic Company, Akron, $\mathrm{OH}$ \\
\hline Coir & Coir 4.0" Std Fiber Gro Pot & 406 & Dillen Products, Middlefield, $\mathrm{OH}$ \\
\hline Manure & \#4 Square CowPot & 450 & CowPots Manufacturing and Sales, East Canaan, CT \\
\hline Peat & $4^{\prime \prime}$ Jiffy Pot & $379^{y}$ & Jiffy Products of America Inc., Lorain, $\mathrm{OH}$ \\
\hline Bioplastic sleeve (Sleeve) & 4.5" Standard Assembled SoilWrap ${ }^{\circledR}$ & $709^{y}$ & Ball Horticultural Company, West Chicago, IL \\
\hline Slotted rice hull & $4.5^{\prime \prime}$ NetPot & 591 & Summit Plastic Company, Akron, $\mathrm{OH}$ \\
\hline Solid rice hull & Rice Pot $4^{\prime \prime}$ & 473 & Summit Plastic Company, Akron, $\mathrm{OH}$ \\
\hline Straw & $\mathrm{N} / \mathrm{A}$ & $646^{\mathrm{y}}$ & Ivy Acres, Baiting Hollow, NY \\
\hline Wood fiber & $10 \times 10-\mathrm{cm}$ round individual Fertilpot & $430^{y}$ & Fertil SAS, Boulogne Billancourt, France \\
\hline
\end{tabular}

${ }^{\mathrm{z}}$ As indicated in manufacturer's online/print catalog.

${ }^{\mathrm{y}}$ Not included in manufacturer specifications. Volume approximated.

$\mathrm{N} / \mathrm{A}=$ not applicable. 


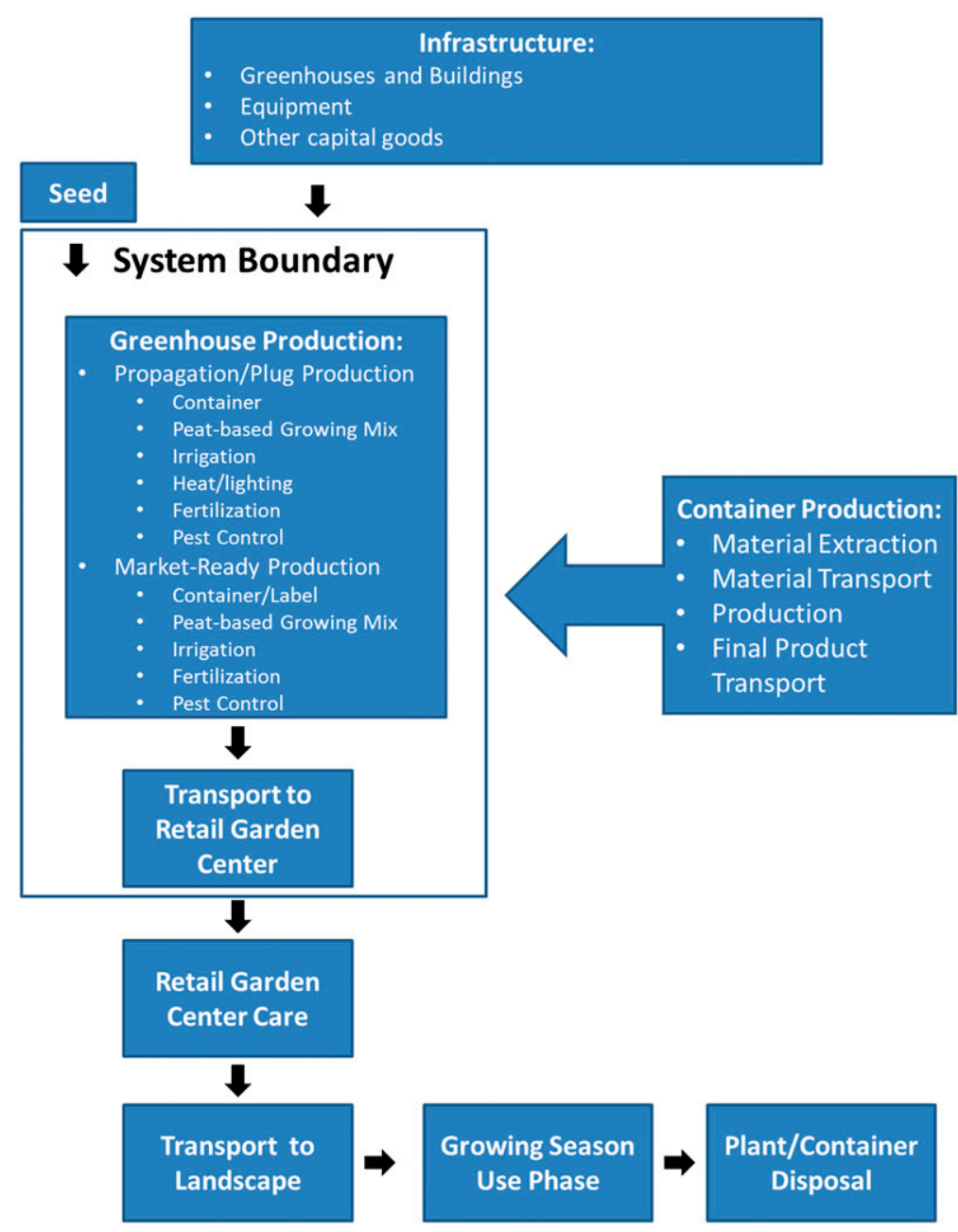

Fig. 2. Life cycle of a greenhouse-produced petunia plant. The system boundary for this cradle-to-gate assessment is outlined.

sources. General production practices for plug and final plant production were identified through a series of telephone and e-mail interviews with six production managers at Mid-American Growers. These communications were supported by direct meter readings from the greenhouse's boiler system, metering of the various electrical systems used in production, information from product labels, and interviews with horticultural equipment manufacturers. Direct experimentation from a series of independent greenhouse trials provided container-specific growing requirements. Basic material data came from past literature, the U.S. Life Cycle Inventory Database (National Renewable Energy Laboratory, 2012) and a North American-adapted version of the Ecoinvent Database (US-EI Version 2.2, Earthshift Inc., Huntington, VT; Earthshift, Inc., 2009). Electricity source information specific to the study area was obtained from the U.S. EPA's Emissions and Generation Resource Integrated Database (eGRID) model (U.S. EPA, 2009). All processes and data sources for the life cycle inventory were managed through the SimaPro LCA software tool (SimaPro 7.3.3; PRé Consultants bv, solution of the plant growth regulator, ethephon (Florel; Lawn and Garden Products, Inc., Fresno, CA), to promote secondary branching and create a bushier appearance. Around this same time, a 1- to 3-ppm solution of paclobutrazol (Piccolo; Fine Agrochemicals, Ltd., Walnut Creek, CA) is sprayed on the plants to reduce stem elongation and limit legginess.

Plug plants are grown in an enclosed double-polypropylene greenhouse space. Supplemental lighting is provided by $600-\mathrm{W}$ highpressure sodium grow lamps covering an area of $10.5 \mathrm{~m}^{2}$ each. Lamps are set so they were on during early mornings and weekends $\left(24 \mathrm{~h} \cdot \mathrm{d}^{-1}\right)$ for a total run time of $73 \mathrm{~h}$ per week. Three wood boilers using chipped industrial wood scrap maintain minimum greenhouse temperatures of 22 to $24^{\circ} \mathrm{C}$. Thirty-year average outdoor highs and lows during the modeled petunia production period are shown in Figure 3.

Inputs and assumptions associated with final greenhouse production (plastic container scenario). Plugs are mechanically transplanted into larger $10-\mathrm{cm}$ polypropylene pots after the initial 4-week plug production phase. During transplanting, empty pots are placed in a 10 -cell polystyrene filling tray and run through a mechanical potting mix filling machine (KV-L Filler; Agronomix, Oberlin, OH). Each container is filled with $\approx 68.4 \mathrm{~g}$ of a $85: 15$ peat:perlite soil-less mix (mixed on-site). After filling, plugs are hand-transplanted into the larger containers, and the trays (with pots and plants) are moved by hand cart outside for the final 5 weeks of production.

Once outside, plants are fertigated using an overheard spray irrigation system every 2 to $3 \mathrm{~d}$ with a $100 \mathrm{ppm}$ nitrogen $14 \mathrm{~N}-2 \mathrm{P}-20 \mathrm{~K}$ fertilizer solution. Average water use for plants grown in plastic containers (without trays) was calculated to be $2162 \mathrm{~mL}$ during an independent growth trial intended to mimic this stage in production (Koeser et al., 2013b). This value was adjusted to reflect water savings (6\%) associated with tray use (Evans et al., unpublished data).

During the final production stage, petunia plants are typically treated once with a fungicide (Banrot; Scotts-Sierra Crop Protection Company, Marysville, $\mathrm{OH}$ ) at a rate of $0.60 \mathrm{~g}$ of wettable powder per liter of water. They are also sprayed once with the fungal-derived insecticide NoFly (Natural Industries, Inc., Spring, TX) at $2.3 \mathrm{~kg} \cdot \mathrm{ha}^{-1}$ to prevent thrip damage and again with the insecticide Mallet (Nufarm Americas, Inc., Burr Ridge, IL) at a rate of $0.12 \mathrm{~g} \cdot \mathrm{L}^{-1}$ to prevent aphid damage. The petunia plants are also sprayed one to two times with a 5 to $6 \mathrm{ppm}$ paclobutrazol growth regulator solution to maintain a compact, full form. Cull rate at this production stage was estimated at $2 \%$ by the interviewees.

Container type-influenced production inputs (secondary impacts). Secondary impacts of container type fall into one of two general categories: impacts related to container size and impacts related to container-related irrigation demand. Differences in container size directly translate into differences in peat and perlite use during the final production 
Table 2. Life cycle inventory for both the plug and final plant product stages. ${ }^{z}$

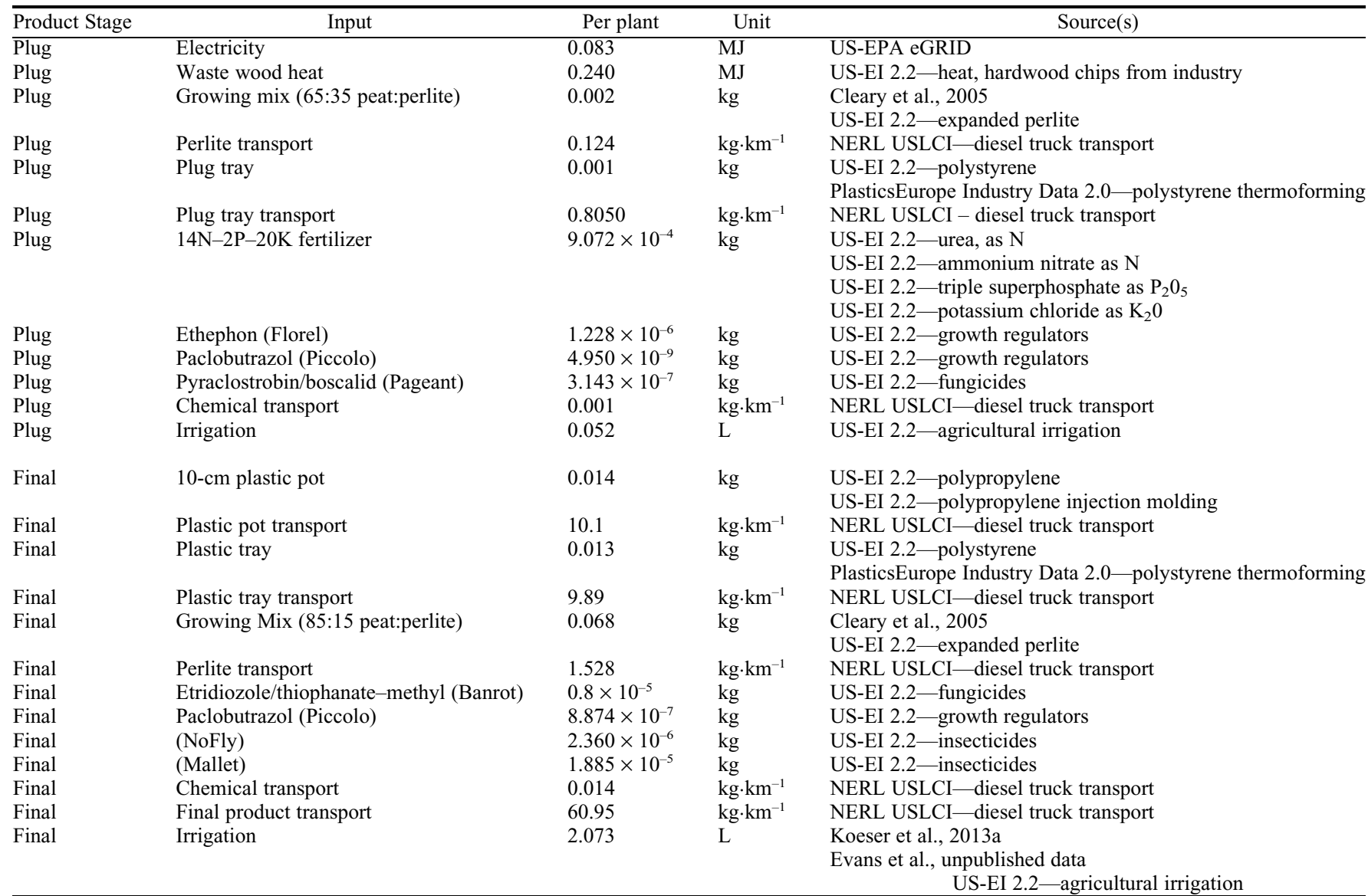

${ }^{\mathrm{z}}$ Data sources included.

$\mathrm{N}=$ nitrogen.

stage and ultimately shipping weight. A $10-\mathrm{cm}$ diameter container size was chosen as a standard given its wide availability among container types. However, two containers, the bioplastic sleeve and the slotted rice pot, were only available in $11.5-\mathrm{cm}$ sizes. Similarly, the manure pot was available in a $10-\mathrm{cm}$ square only (not a round like the other nine containers). Lastly, the straw pot, although $10 \mathrm{~cm}$ in diameter, had a larger volume than most containers given its above-average height.

Water use, although tied in part to container volume, is also influenced by container geometry (i.e., slender vs. stout), absence or presence of drain holes, and container wall porosity. Differences in water demand influence the amount of electricity required to run irrigation systems. Additionally, all fertilization, pesticide, and growth regulator applications were administered in conjunction with normal irrigation. As such, the amount of chemical applied would vary slightly by container depending on the amount of water dispensed in a given watering.

Inputs and assumptions for transportation. All pesticides, fertilizers, and the commercially produced plug growing mix were assumed to have come from the nearest major greenhouse supplier (110 km from the study site; BFG Supply Company, Joliet, IL). The horticultural peat material data used for the two growing media mixes included an estimate for average delivery in North America (Cleary et al., 2005). However, the expanded perlite component of this mix did not include a transportation component (US-EI 2.2). As such, perlite was assumed to be sourced and delivered from the nearest processing plant (148 km to study site; Silbrico Corporation, Hodgkins, IL). Finally, transportation for the plastic containers and trays was assumed to be the distance to the manufacturer $(740 \mathrm{~km}$ to study site; Meyers Industries, Middleton, $\mathrm{OH}$ ). For all inputs, transportation by diesel truck was assumed.

Plants are transported only minimally during greenhouse production. Throughout the entire process, plants are moved $\approx 0.75 \mathrm{~km}$ by lawn tractor or by person (latter assumed). Mid-American Growers provides floral materials to a wide range of major retailers within $480 \mathrm{~km}$ of the production site. The largest market in this distribution area is the Chicago, IL, metropolitan area (174 km from Chicago to the production site). This was the assumed destination for the final product.

Impact assessment and life cycle assessment. In addition to assessing the overall GWP of a petunia plant produced in a conventional plastic container, GWP values were estimated for the 10 different container production scenarios using the U.S. EPA's TRACI 2 impact assessment model [Version 4.00 (US EPA, 2012)]. Only processes contributing
$0.5 \%$ or more toward the overall environmental impact of a petunia are included in the result summaries.

Sensitivity analysis was conducted to see how the overall GWP impact results changed with the inclusion of a given container parameter (Björklund, 2002; ISO 14044, 2006). Overall differences of $15 \%$ to $30 \%$ in an impact category (GWP in this case) are considered significant by LCA practitioners when identifying influential inputs (Harnoor Dhaliwal, personal communication).

\section{Results and Discussion}

Baseline assessment of petunia production. GWP for all of the main contributing inputs are expressed as kilograms of carbon dioxide equivalents $\left(\mathrm{kg} \mathrm{CO}_{2} \mathrm{e}\right)$ in Table 3. For plug production, the overwhelming majority of $\mathrm{kg} \mathrm{CO} 2 \mathrm{e}$ was linked to electrical consumption. The majority of the electricity used to propagate and grow petunia seedlings was used for supplemental lighting.

Wood heating was a minimal contribution to GWP (Table 3). Of the three boilers used, only two were needed intermittently to heat an area of 8 ha. When in operation, the boilers heated a large buffer tank, which helped limit temperature fluctuations as nighttime temperatures dropped. The fuel source used by the boilers also served to limit over GWP. All 


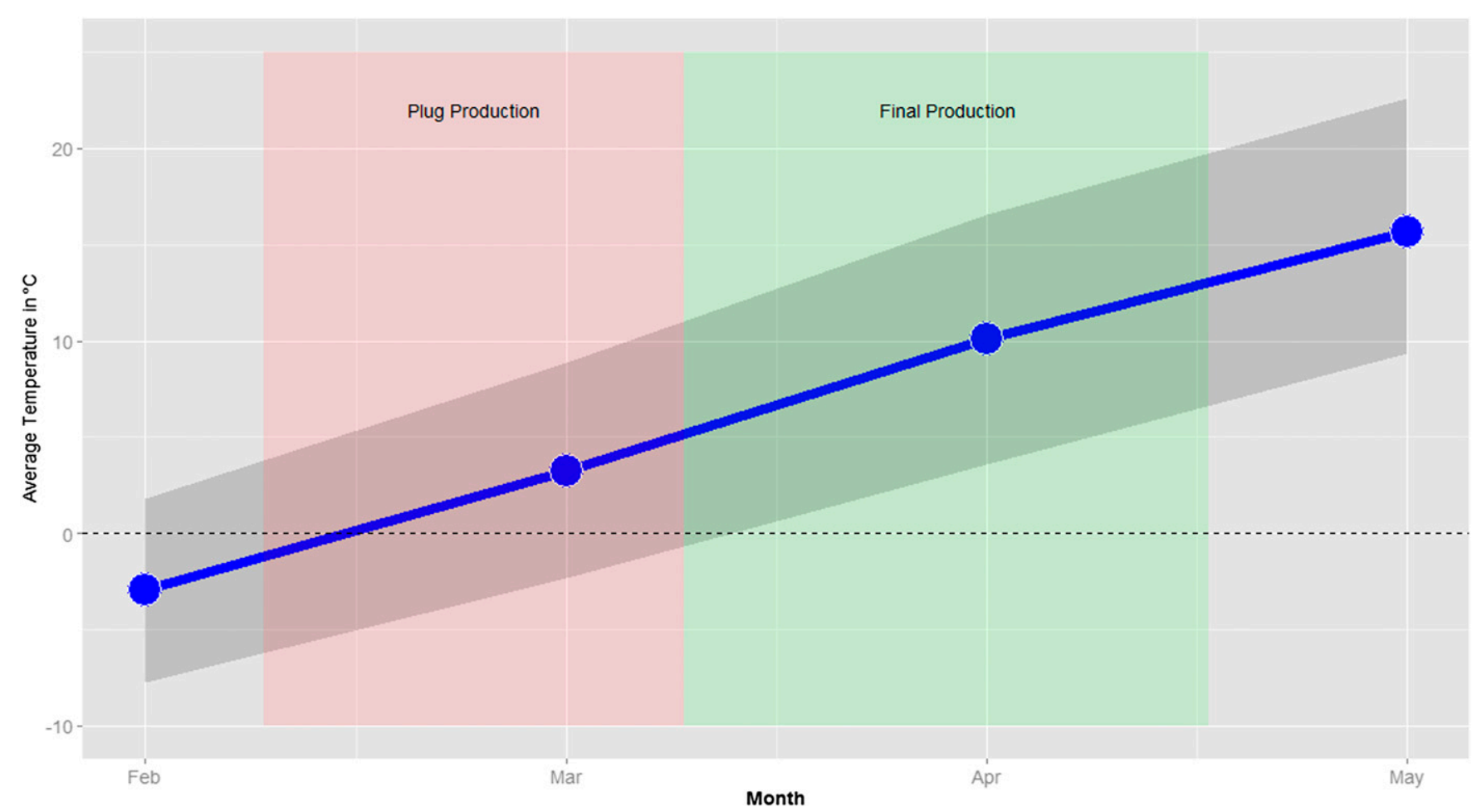

Fig. 3. Monthly average temperatures for Granville, IL, study site (data represent mean 30-year highs, averages, and lows recorded at a nearby weather station in nearby Peru, IL) during the assumed production period.

Table 3. Base-level inputs, transportation requirements, and their associated $\mathrm{CO}_{2} \mathrm{e}$ emissions per petunia plant grown in a plastic container.

\begin{tabular}{llcc}
\hline Product stage & \multicolumn{1}{c}{ Input $^{\mathrm{z}}$} & $\mathrm{kg} \mathrm{CO}_{2} \mathrm{e}$ & Percent contribution to total GWP \\
\hline Plug & Electricity (lighting and irrigation) & 0.254 & 94.8 \\
Plug & Waste wood heat & 0.003 & 1.1 \\
Plug & Growing mix & 0.002 & 0.7 \\
Plug & Plug tray & 0.009 & 3.4 \\
& Plug total & 0.268 & 100.00 \\
& & & \\
Final & Finished plug & 0.268 & 49.3 \\
Final & Transportation-truck & 0.017 & 3.1 \\
Final & Horticultural peat & 0.042 & 7.7 \\
Final & Expanded perlite & 0.012 & 2.2 \\
Final & Fertilizer solution & 0.009 & 1.7 \\
Final & Plastic container & 0.087 & 16.0 \\
Final & Plastic shuttle tray & 0.109 & 20.0 \\
& Plant total (including plug) & 0.544 & 100.00 \\
\hline
\end{tabular}

${ }^{2}$ Only inputs contributing $0.5 \%$ or more toward the emissions for a given production stage are included. $\mathrm{GWP}=$ global warming potential.

woodchips were sourced locally as industrial byproducts from pallet and other manufacturing processes (nearest supplier $30 \mathrm{~km}$ away).

The remainder of the inputs had minimal impact given the diminutive size of the plant and plug tray cell. Only horticultural peat and polystyrene (materials with processes noted for their $\mathrm{CO}_{2} \mathrm{e}$ emissions) were present in sufficient quantities (by mass) to register as noteworthy contributors to GWP.

Plug production in the controlled greenhouse space accounted for nearly half of the final plant's carbon footprint (Fig. 4). Other notable inputs in petunia production included: tray ( $20.0 \%$ of total GWP); container ( $16.0 \%$ of total GWP); and peat $(7.7 \%$ of total GWP). Lesser contributors to the overall impact included: transport (3.1\% of total GWP); perlite $(2.2 \%$ of total GWP); and the fertilizer (1.7\% of total GWP).

These results offer a comparison with past cradle-to-gate carbon footprint assessment of container woody ornamental production (Kendall and McPherson, 2012) and tree seedling production (Aldentun, 2002). In the first study, a total of $4.6 \mathrm{~kg} \mathrm{CO}_{2} \mathrm{e}$ was emitted during the production of a typical \#5 (13.5-L capacity) container tree. Like with petunia production, the researchers noted that inputs were more intensive during propagation and seedling production. Although grown over several seasons, the latter stages of tree production, like petunia production, occur outdoors in uncontrolled environments. Kendall and McPherson (2012) also note containers, growing media, and fertilizer as significant material inputs during final production. Aldentun (2002) calculated $\mathrm{CO}_{2} \mathrm{e}$ emissions ranging from 0.045 to $0.133 \mathrm{~kg}$ per seedling with the variation linked to nurseries surveyed. Again, lighting, peat, and tray were identified as significant contributors to overall GWP.

Secondary impacts associated with biocontainer use. Although past research has shown biocontainer use can have significant impacts on inputs like irrigation (Koeser et al., 2013a), this variability did not translate into significant differences in GWP. In assessing the various container parameters, GWP differed by $14.4 \%$ between the lowest and highest ranked container types: sleeve and peat (Fig. 5). Although close to the more conservative $15 \%$ significance level mention in the "Methods," one could argue this difference is confounded with container size. Petunias grown in the six $10-\mathrm{cm}$ diameter biocontainers had nearly identical GWP values as a petunia grown in the conventional plastic pot (also $10 \mathrm{~cm}$ in diameter).

The three most noticeable differences in GWP associated with secondary impacts of containers are seen with the sleeve, slotted rice, and straw containers (Fig. 5). These are also the three most voluminous pots (Table 1). All containers are filled to capacity by the mechanical filling machine. As such, differences in peat use and final shipping weight drive the elevated GWP for these three containers. Other inputs such as irrigation, fertilization, and pesticides appear to have a lesser influence on GWP, because their use was reduced (compared with plastic) in the sleeve and slotted rice containers, yet overall 


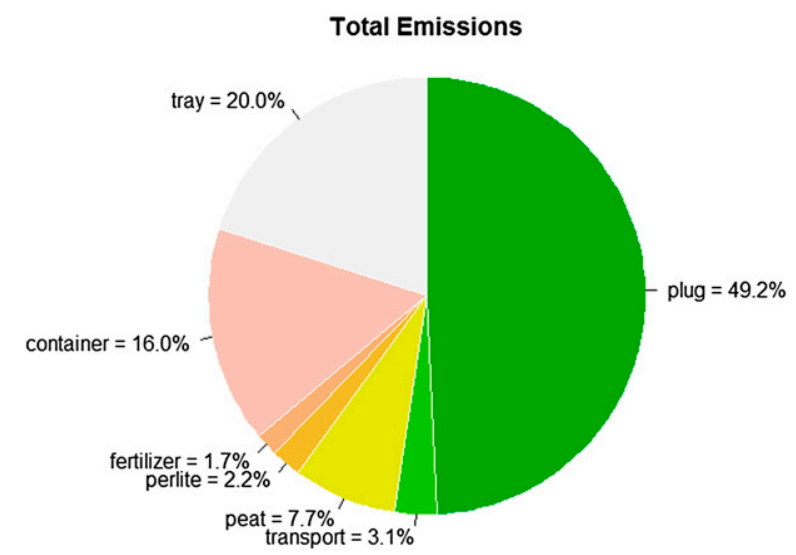

Fig. 4. Percentage of greenhouse gas emissions associated with petunia production system components with a conventional plastic container. Only inputs contributing $0.5 \%$ or more are included.

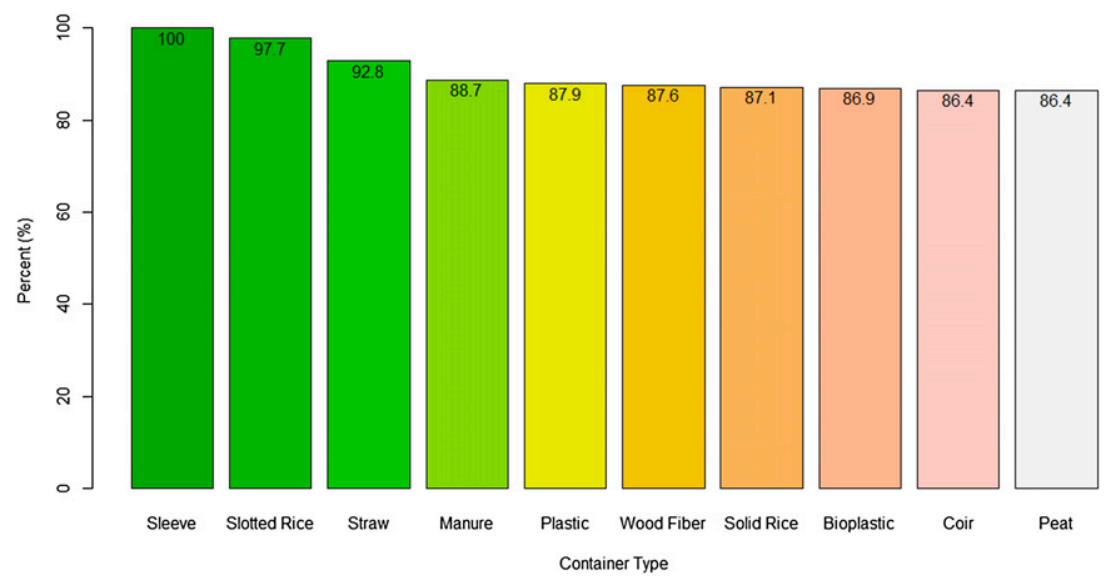

Fig. 5. Comparison of petunia production global warming potential (GWP) when using one of nine biocontainers or a conventional plastic container $\left(\mathrm{CO}_{2} \mathrm{e}\right.$ for sleeve set at $\left.100 \%\right)$. Differences reflect only secondary impacts and do not include $\mathrm{CO}_{2} \mathrm{e}$ emissions associated with the production of the biocontainers themselves.

carbon emission was still elevated for these two pots.

In conducting this assessment, we chose each biocontainer manufacturer's closest alternative to the common $10-\mathrm{cm}$ plastic pot. If a grower switched from this size to one of the three larger biocontainers, the differences noted below could warrant further investigation. However, it seems likely that if all container sizes were identical, the differences in GWP would have been negligible.

\section{Conclusion}

The results of this work should be encouraging for growers and manufacturers looking to increase sustainability through the use and development of biocontainers. Although biocontainers have been linked to reduced performance in plant growth, filling speed, shipping success, and irrigation demand trials, these differences do not have a dramatic effect on production sustainability from a GWP perspective.

Furthermore, variability in plant size may be tolerated by consumers and growers as long as plant appearance remains unaffected. the real and perceived environmental impacts associated with greenhouse-grown petunias by adopting more efficient lighting and biocontainers in their operations.

\section{Literature Cited}

Aldentun, Y. 2002. Life cycle inventory of forest seedling production-From seed to regeneration site. J. Clean. Prod. 10:47-55.

Björklund, A.E. 2002. Survey of approaches to improve reliability in LCA. Intl. J. Life Cycle Assessment 7:64-72.

Boustead, I. 1996. LCA - How it came about. Intl. J. Life Cycle Assessment 1:147-150.

British Standards Institute. 2011. PAS2050: Specification for the assessment of the life cycle greenhouse gas emissions of goods and services. British Standards Institute, London, UK.

Cleary, J., N.T. Roulet, and T.R. Moore. 2005 Greenhouse gas emissions from Canadian peat extraction, 1990-2000: A life cycle analysis. Ambio 34:456-461.

Dennis, J.H., R.G. Lopez, B.K. Behe, C.R. Hall, C. Yue, and B.L. Campbell. 2010. Sustainable production practices adopted by greenhouse and nursery plant growers. HortScience 4:1232-1237.

Earthshift, Inc. 2009. US-EI 2.2. Earthshift, Inc., Huntington, VT.

Evans, M.R. and D. Karcher. 2004. Properties of plastic, peat, and processed poultry feather fiber growing containers. HortScience 39:10081011

Evans, M.R., M. Taylor, and J. Kuehny. 2010 Physical properties of biocontainers for greenhouse crops production. HortTechnology 20:549555.

Garthe, J.W. and P. Kowal. 1994. Recycling used agricultural plastics. Cooperative Extension. Fact Sheet. Agricultural and Biological Engineering-Pennsylvania State University, University Park, PA. December 2012. <http:// www.abe.psu.edu/extension/factsheets/c/C8.pdf $>$.

Hall, C.R., B.L. Campbell, B.K. Behe, C. Yue, R.G. Lopez, and J.H. Dennis. 2010. The appeal of biodegradable packaging to floral consumers HortScience 45:583-591.

Hall, T.J., J.H. Dennis, R.G. Lopez, and M.I. Marshall. 2009. Factors affecting growers' willingness to adopt sustainable floriculture practices. HortScience 44:1346-1351.

Ingram, D.L. 2012. Life cycle assessment of a fieldgrown red maple tree to estimate its carbon footprint components. Intl. J. Life Cycle Assessment 17:453-462.

Ingram, D.L. 2013. Life cycle assessment to study the carbon footprint of system components for Colorado blue spruce field production and use. J. Amer. Soc. Hort. Sci. 138:3-11.

ISO 14044. 2006. Environmental managementLife cycle assessment-Requirements and guidelines. 2006. International Organization for Standardization, Geneva, Switzerland

Kendall, A. and E. McPherson. 2012. A life cycle greenhouse gas inventory of a tree production system. Intl. J. Life Cycle Assessment 17:444452.

Koeser, A.K., S.T. Lovell, M.R. Evans, and J.R. Stewart. 2013a. Biocontainer water use in short-term greenhouse crop production. HortTechnology 23:215-219.

Koeser, A.K., G. Kling, C. Miller, and D. Warnock. 2013b. Compatibility of biocontainers in commercial greenhouse crop production. HortTechnology 23:149-156.

Krug, B.A., S.E. Burnett, J.H. Dennis, and R.G. Lopez. 2008. Growers look at operating a sustainable greenhouse. GMPro. 
Kuehny, J.S., M. Taylor, and M.R. Evans. 2011. Greenhouse and landscape performance of bedding plants in biocontainers. HortTechnology $21: 155-161$.

National Renewable Energy Laboratory. 2012. U.S. life cycle inventory database. March 2013. <https://www.lcacommons.gov/nrel/ search $>$.

PlasticsEurope, various (date unkown) Industry data 2.0
U.S. Environmental Protection Agency. 2009 eGrid-Emissions \& Generation Resource Integrated Database. Mar. 2013. <http://www. epa.gov/cleanenergy/energy-resources/egrid/ index.html $>$.

U.S. Environmental Protection Agency. 2011. Plastics - Common wastes \& materials. Overviews \& Factsheets. November 2012. <http:// www.epa.gov/osw/conserve/materials/plastics. htm\#facts>.
U.S. Environmental Protection Agency. 2012. TRACI 2-Tool for the reduction and assessment of chemical and other environmental impacts. March 2013. <http://www.epa.gov/ $\mathrm{nrmrl} / \mathrm{std} / \mathrm{sab} / \mathrm{traci} / \mathrm{\text {. }}$.

Yue, C., J.H. Dennis, B.K. Behe, C.R. Hall, B.L. Campbell, and R.G. Lopez. 2011. Investigating consumer preference for organic, local, or sustainable plants. HortScience 46:610615 